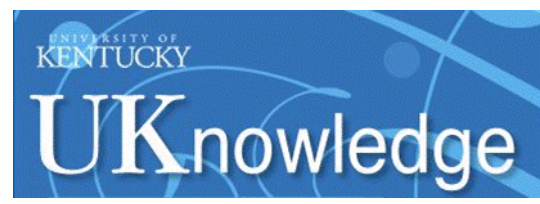

Kentucky Law Journal

Volume 26 | Issue 1

Article 4

1937

\title{
Equitable Conversion by Contract
}

R. T. Miller

Follow this and additional works at: https://uknowledge.uky.edu/klj

Part of the Contracts Commons, and the Property Law and Real Estate Commons

Right click to open a feedback form in a new tab to let us know how this document benefits you.

\section{Recommended Citation}

Miller, R. T. (1937) "Equitable Conversion by Contract," Kentucky Law Journal: Vol. 26: Iss. 1, Article 4.

Available at: https://uknowledge.uky.edu/klj/vol26/iss1/4

This Note is brought to you for free and open access by the Law Journals at UKnowledge. It has been accepted for inclusion in Kentucky Law Journal by an authorized editor of UKnowledge. For more information, please contact UKnowledge@lsv.uky.edu. 


\section{NOTES}

\section{EQUTTABLE CONVERSION BY CONTRACT}

Lord Esher, M. R., said of maxims, "I need hardly repeat that I detest the attempt to fetter the law by maxims. They are almost invariably misleading; they are for the most part so large and general in their language that they always include something which really is not intended to be included in them."1 As often as not the converse of a maxim can be spoken with as much truth as the maxim itself. Yet, upon a maxim, as obnoxious to objection as any maxim, namely, "Equity looks upon that as done which ought to be done," is founded one of the most universally accepted doctrines of the entire field of equity, the doctrine of equitable conversion. ${ }^{2}$

According to this doctrine as soon as a contract for the sale of land is entered into, it makes the purchase money a part of the personal estate of the vendor, and it makes the land a part of the real estate of the vendee. ${ }^{3}$

The doctrine of equitable conversion may be said to have originated in a single court and that the English Court of Chancery. It was probably first expressed in its modern form by Lord Eldon in the case of Seaton v. Slade $e^{4}$ as follows :

"The effect of a contract for purchase of land is very different at Law and in Equity. At Law the estate remains the estate of the vendor; and the money that of the vendee. It is not so here. The estate from the sealing of the contract is the real property of the vendee. It descends to his heirs. It is devisable by his will; and the question whose it is is not to be discussed merely between the vendor and the vendee; but may be discussed between the representatives of the vendee."

${ }^{1}$ Yarmouth v. France, 19 Q. B. D. at 653 (1887).

${ }^{2}$ Craig v. Leslie, 16 U. S. (3 Wheat.) 563, 4 L. Ed. 460 (1818); Loughborough v. Loughborough, $53 \mathrm{Ky}$. (14 B. Mon.) 549 (1854); Collins v. Champ, $54 \mathrm{Ky}$. (15 B. Mon.) 118 (1854); Rodisch v. Moore, 266 Ill. 106, 107 N. E. 108 (1914); Baker ₹. Commissioner of Corporations and Taxation, 253 Mass. 130, 148 N. F. 593 (1925); Turner v. Hine, 297 Mo. 153, 248 S. W. 933 (1923); Moore v. Kernachan, 133 Va. 206, 112 S. E. 632 (1922); Schneider v. Schneider, 135 Kan. 734, 12 Pac. (2d) 834 (1932); Suttler v. Ling, 25 Pa. 466 (1854).

${ }^{3}$ Lysaght v. Edwards (1867), L. R. 2 Ch. Div. 499; Collins v. Combs, $160 \mathrm{Ky} .325,169 \mathrm{~S}$. W. 721 (1914).

$\$ 7$ Ves. Jr. 265 (1802). But see Lord King in Milner v. Milner, Mosley 123 (1792). 
The most commonly accepted view of this doctrine was stated by Jessel, M. R., in Lysaght v. Edwards ${ }^{5}$ in commenting on the legal consequences of entering into a contract for the sale of land or any contract specifically enforceable as follows :

"Being a valid contract it has this remarkable effect, that it converts the estate, so to say, in Equity; it makes the purchase money a part of the personal estate of the vendor, and it makes the land a part of the real estate of the vendee, and therefore all those cases on the doctrine of constructive conversion are founded simply on this, that a valid contract actually changes the ownership of the estate in Equity."

As has been said this doctrine is well founded in Equity and receives almost universal acceptance, but more recently some of our best writers have begun to investigate and to study the basis of the doctrine and have criticised it thoroughly and pointed out the fallacies of the doctrine. ${ }^{6}$ Some of the state legislatures have undertaken to step in and cure some of the defects, ${ }^{7}$ and even a few judges have broken all precedent and delved into the subject far enough to see that the doctrine of

supra, n. 3.

"Stone-"Equitable Conversion by Contract", 13 Col. L. Rev. 369. Simpson-"Legislative Changes in the Law of Equitable Conversion by Contract", 44 Yale L. J. 559, 754.

"This particular corner of the law was for a long period unusually free from legislative interference. The applicable principles were developed in a single court-the English Court of Chancery-beginning early in the seventeenth century and reaching logical symmetry some two hundred years later in the decisions of Lord Eldon and in the writings of Sugden. Later developments were regarded as being logical deductions from established doctrines. To be sure, there have been divergencies of view on some matters, but these have been due, for the most part, to differences in what has been deemed sound deductive reasoning from accepted principles rather than to any questioning of those premises or conscious reliance upon consideration of mundane convenience or practical justice. This corner of property law thus has, like that which includes the classic learning as to contingent remainders and as to the classification of the Rule against Perpetuties, an almost mathematical atmosphere. Langdell's elaboration of the doctrine of Equitable Conversion, which is the classic American exposition from a theoretical standpoint, is as much a legal geometry as is Fearn's famous Essay. But even in this heaven of juristic conceptions, the a-logical influence of the legislator has been making itself felt in recent years; and it is no longer possible to solve all problems involving Equitable Conversion by deductive reasoning from the principles laid down by the English Chancellors and systematized by Sugden and Langdell."

'44 Yale L. J. 559, 561. 
equitable conversion is not a panacea in determining the rights of the parties in cases of contracts for the sale of land. ${ }^{8}$

Even though the courts have accepted the doctrine of equitable conversion, they have admitted that it is purely a fiction and is a creature of equity, unknown to the law ${ }^{9}$ and will be invoked only when necessary to accomplish manifest justice. ${ }^{10}$

If this be true, then if the same manifest justice may be reached through the application of settled and well established legal principles the aid of the theory of equitable conversion should never be involked.

Let us now attempt to see if we can discover any set of facts in which we cannot reach the same, if not more equitable, and just results by the use of well established legal principles as we do by applying the theory of equitable conversion and at the same time show some instances wherein if the theory is invoked no equitable or just result can possibly be attained.

Professor Stone"11 says: "It is obvious that all occasions for the application of the doctrine of equitable conversion by contract will arise in connection with one or two classes of cases, which may be enumerated as follows:

1. Where the contract is actually being specifically performed.

2. Where there is no specific performance of the contract but where the court is called upon to determine what person or class of person is entitled to the real estate which is the subject of the contract, on the one side, and the purchase money, which is obligated to be paid, on the other."

Under the first class the court is actually engaged in compelling the conversion which according to the theory of equitable conversion has already been converted. Then in order to test the utility of the fiction all that is necessary to be done is to see whether or not the same result can be reached by the application of well established legal principles.

Suppose that A contracts in November to sell land to B, conveyance to be made in March. If both $A$ and $B$ are alive at

${ }^{8}$ Mackey v. Sherman, 263 Ill. App. 109 (1932).

"The doctrine of Equitable Conversion, while generally true, is not without its exceptions." .

"Moore v. Kernachan, supra, n. 2.

${ }^{10}$ State v. O'Connell, 121 Wash. 542, 209 Pac. 865 (1922).

113 Col. L. Rev. 369, 372. 
the time set for the conveyance everything works out all right and there is no need for Equity to interfere unless asked at that time to decree specific performance. But the problem is not so simple if either $A$ or $B$ or both die between the sealing of the contract and the time set for delivery. The question then arises, in the distribution of the estate, as to just whom, the heir or the personal representative, the land in the case of $A$, the vendor, and the money in the case of $B$, the vendee, should go. If the contract had been carried out prior to A's death then the land which $A$ had would have been exchanged for money and that money would have gone, at A's death to the personal representative of $A$. But if there had been no contract concerning this land, or if $A$ at the time of his death were still considered the owner of this land, it, the land, would have descended to A's heir. Likewise in the case of $B$, the vendee. If there had been no contract the money would have gone at B's death to the personal representative of $B$, but if the contract had been carried out prior to B's death that money would have been then exchanged for land and the land being realty would therefore have descended to B's heir. Since this is the case it is true that all of these parties have an interest in the subject matter of this contract. So equity has, by invoking the aid of the maxim that "Equity looks upon that as done which ought to be done," looked upon the contract as having been carried out as of the time of the sealing of the contract; ${ }^{12}$ thereby converting the realty into personalty and vice versa. ${ }^{13}$

Some cases have treated the vendor in such a contract as a trustee of the land for the vendee and the vendee as a trustee of the purchase money for the vendor. ${ }^{14}$ This statement though

${ }^{2}$ Fletcher v. Ashburner, 1 Bro. C. C. 497 (1779).

${ }^{13}$ See Clark, Equity, Sec. 448 (1919).

"By strict logic equity-in following the maxim-should have regarded the conversion as taking place at the time that the trustees should have converted it but unless there was a time fixed for such conversion, it would be the duty of the trustees to make the sale or the investment within a reasonable time and it would be obviously undesirable to have the question of the coming into existence of equitable property rights open to such an uncertainty as the lapse of a reasonable time. Hence courts were compelledconsciously or unconsciously - to fall back upon the certain time of the taking effect of the will or deed."

"Masterson v. Pullen, 62 Ala. 145 (1878); N. Y. Cent. \& H. R. R. Co. v. Cottle, et al., 168 N. Y. S. 463, 102 Misc. Rep. 30 (1917); Stewart

K. L. J. -5 
containing a germ of truth is obviously inaccurate. The vendor is unlike a trustee in many particulars. $\mathrm{He}$, the vendor, has a personal interest in the land; he is entitled to the rents, issues, and profits until the date of performance, ${ }^{15}$ he holds the title as security for the payment of the purchase money $;^{16}$ the proceeds of the insurance effected by him he holds for his own benefit and not the benefit of the vendee. ${ }^{17}$ The vendee, on the other hand, is a mere debtor. He holds no specific property for the vendor, and his sole obligation in law and in equity is to pay the purchase money on the conveyance of the vendor's title. More accurately stated, the obligation of the vendor in equity is to convey land to the vendee. The vendee is the owner of the correlative right in equity to have the vendor convey.

The result, therefore, in the case of a contract for the sale of land, where prior to time for conveyance both the vendor and the vendee die, without invoking the aid of the theory of equitable conversion, is that the vendee's heir receives the same right to specific performance which had vested in the vendee. The vendor's heir takes the land subject to the obligation to convey, not because he is subject to any contract obligations, but because he is in the precise position of a donee of property held subject to an equitable obligation. He will not be permitted to retain that property in violation of that obligation any more than would a donee of trust property be permitted to retain it. The right to receive the purchase money has vested in the personal representative of the vendor, since the right to the proceeds of the contract, which is personal, has rightly descended to the personal representative. The personal representative of the vendee is bound to pay the purchase money for the simple reason that all obligations in contract as a matter of law fall and rest upon the personal representative of the deceased debtor or obligor.

So, through the mere application of settled legal principles we have reached the same result which we would have reached had we invoked the aid of the theory of equitable con-

v. Griffith, 31 App. D. C. 29; affirmed, 217 U. S. 323, 30 s. Ct. 628 (1908); Collins v. Combs, $160 \mathrm{Ky} .325,169 \mathrm{~S}$. W. 721 (1914).

1s Townley v. Bedwell, 14 Ves. Jr. 591 (1808).

I6 Moore v. Burrows, et al., 34 Barb. (N. Y.) 173 (1861).

${ }^{17}$ Raynor v. Preston, L. R. 18 Ch. Div. 1 (1881). 
version. It will probably then be suggested that as we have merely reached the same result that the fiction could do no harm and that it does provide a convenient method for explaining the result so reached. But this is not true in all cases. "The difficulty with this view is that the test of equitable conversion, viz. the sealing of the contract, for the sale of land *** breaks down wholly in those cases where by reason of defective title, failure to comply with the statute of frauds, hardship, or a reserved right to reseind the contract, a defense is interposed to an action for the specific performance of the contract."18

The inconsistency in which the courts have become involved by attempting a logical application of the doctrine of equitable conversion is exemplified in the case of option contracts. Professor Langdell has pointed out that an option is not an offer to enter into a bilateral contract, but is a promise to convey on the happening of a certain condition, viz., the payment of the purchase price. ${ }^{19}$ However, a majority of the courts hold that an option is an offer to enter into a bilateral contract upon the happening of a stipulated condition evidencing the option vendee's intention to exercise the option. However, whether an option be considered a promise or an offer it is clearly seen that it is not such a contract as the courts will decree specific performance on, before the notice of the vendee's intention to exercise such option. Suppose then in the case of an option contract the option vendor dies prior to the exercising of the option by the option vendee. Certainly as there has been no contract specifically enforceable there has been no equitable conversion. The land descends to the vendor's heir and the heir takes subject to the obligation to convey upon the exercising of the option by the option vendee. According to the doctrine of equitable conversion, that the conversion takes place at the time of the sealing of the contract, then when the option vendee exercises his option and there is a "sealing of the contract" the land has already descended to the heir completely and the heir being the complete owner would be entitled to the purchase money. But, in fact, this is not the desired result since as a matter of law the personal representative is supposed to receive

${ }^{28}$ Stone, 13 Col. L. Rev. 369, 375.

${ }^{9}$ Langdell, "Equitable Conversion", 18 Harv. L. Rev. 2; Langdell, A Brief Survey of Equity Jurisdiction, p. 261. 
the proceeds of the contract, which of itself is personalty. So to avoid this discrepancy, and still hold to the fiction of equitable conversion, the courts have coined another fiction, that of relation; saying that when the option is exercised and the contract is sealed, that it relates back to the date of the giving of the option, thus somehow jerking the title which it has placed in the heir out of the heir and making the conversion take place as of the date of the giving of the option, ${ }^{20}$ which says in effect that the heir has been holding personalty and the personal represtative of the option vendee has been enjoying the use of realty.

"Legal fictions are often relied upon by courts to prevent a failure of justice, but it is believed that no other case will be found in the books where courts have made use of a fiction for the purpose of divesting rights deemed to have beeen honestly acquired."

However the personal representative's right to receive this purchase money does not rest upon this fiction, but is based upon the legal principles of the devolution of decedent's propperty. ${ }^{22}$ The heir has taken the land as a donee of property subject to an option. The rights under this option to receive the proceeds of the contract when and if it is made are personal and therefore go to the personal representative.

Likewise in the case of the heir and personal representative of the vendee. The right to receive the land which will be the subject of the contract when and if the option is exercised goes to the heir because the land is realty. The personal representative is obligated to pay the purchase price since if he refused he would be unjustly enriched at the expense of the heir, a situation which equity will not permit.

It is apparent that these cases not only do not rest upon any doctrine of equitable conversion, but that it is not a safe or intelligible guide to the results actually reached by the decisions.

There still remains for consideration the case where, pending performance of the contract for the sale of land, a sub-

${ }^{20}$ Smith v. Lowenstein, 50 Ohio St. 346 (1893); Rockland Co. v. Leary, 203 N. Y. 469 (1911). But see Lawes v. Bennett, 1 CoX Eq. Cas. 167 (1785).

${ }^{22}$ Langdell, A Brief Survey of Equity Jurisdiction, p. 272. 
stantial part of the subject matter of the contract is destroyed through no fault of the vendor. On whom should this loss fall? Obviously if the doctrine of equitable conversion is appled then because the vendee is really the owner of the premises the loss should fall on him. ${ }^{23}$ But is this an equitable result? The time comes for the performance of the contract. The vendee because of this depletion in value does not want to carry out the contract and pay the price called for by the contract, but the vendor goes into Equity and asks a decree of specific performance. Should this decree be granted? If the court holds to its fiction of equitable conversion it must grant the decree. But here is the situation. Say for example the contract called for the conveyance of a house and lot, the house valued at $\$ 5,000$ and the lot valued only at $\$ 1,000$. The house has burned between the time of the maling of the contract and the time specified for conveyance. What the vendor then is asking is that the vendee be compelled to deliver over his part of the contract, the full purchase price while he, the vendor can only partially fulfill his obligation. It is impossible for the vendor to even tender what the contract demands that he convey. The doctrine of equitable conversion says that the land already belongs to the vendee and that the loss is his, but is this equitable? The vendee has not enjoyed the possession, nor has he received any of the rents and profits. ${ }^{24}$

The problem of risk of loss under a contract for the sale of land has been much discussed by legal writers, and at least five different theories have been advanced. ${ }^{25}$ These are:

1. That the risk of loss should be on the vendor until legal title is conveyed.20

2. That the risk of loss should be on the vendor until the time agreed upon for the conveyance of the legal title, and thereafter on the purchaser, unless the vendor is then in such

${ }_{23}^{4}$ Pomeroy, Equity Jurisprudence, Sec. 1406.

"It follows therefore (from the doctrine of equitable conversion), that the purchaser being the equitable owner is entitled to all the benefits and assumes all the risks of ownership."

${ }^{21}$ McGinley v. Forest, 107 Neb. 309, 186 N. W. 74 (1921). But see dissent by Dean, J., in this case.

$=$ Chaffee and Simpson, Cases on Equity, 961.

2" Stone, "Equitable Conversion by Contract", 13 Col. L. R. 369. See also 12 Col. Law R. 257. 
default as to be then unable to specifically enforce the contract. ${ }^{27}$

3. That the risk of loss should be on the party in possession, whether the vendor or purchaser. ${ }^{28}$

4. That the risk of loss should be on the vendor unless there is something in the contract or the relations of the parties from which the court can infer a different intention. ${ }^{20}$

5. That the risk of loss should be on the purchaser from the time the vendor-purchaser relation arises. ${ }^{30}$

The writer thinks that the view expressed in number four, that is, that the loss should be on the vendor unless there is something in the contract or the relation of the parties from which the court can infer a different intention, is the most nearly equitable and just view, but wishes to explain further that the phrase, "something in the contract or the relation of the parties from which the court can infer a different intention" should include a consideration of the following: who is in possession; who is bearing the burden of taxes; who is receiving the rents and profits from the land; and whether or not a note has been given for the purchase price upon which the purchaser is paying interest.

From a consideration of all of these cases the fallacies and inconsistencies resulting in the application of the theory of equitable conversion may be clearly seen. True these may all be regarded as being logical deductions from established premises but the fault has been, not in the deductive reasoning, but in the blind acceptance of the major premises as true without ever questioning the soundness of such major premises. No matter how sound the deductive reasoning be, if the premises from which the deduction is made be unsound, how then can the results of the deductions be sound?

R. T. MULLER.

${ }^{27}$ Langdell, Brief Survey of Equity Jurisdiction (2d ed.), 58-65.

${ }^{28}$ Williston, "The Risk of Loss after an Executory Contract for Sale in the Common Law", 9 Harv. L. R. 106; 2 Williston on Contracts, Secs. 927-953.

2 Vanneman, "Risk of Loss in Equity Between the Date of the Contract to Sell Real Estate and Transfer of Title", 8 Minn. L. R. 127.

so Keener, "The Burden of Loss as an Incident of the Right to Specific Performance of a Contract", 1 Col. L. R. 1; 5 Pomeroy, Equity Jurisprudence (4th ed.), Sec. 2282; Pound, "Progress of the Law-Equity", 33 Harv. L. R. 813, 826. 